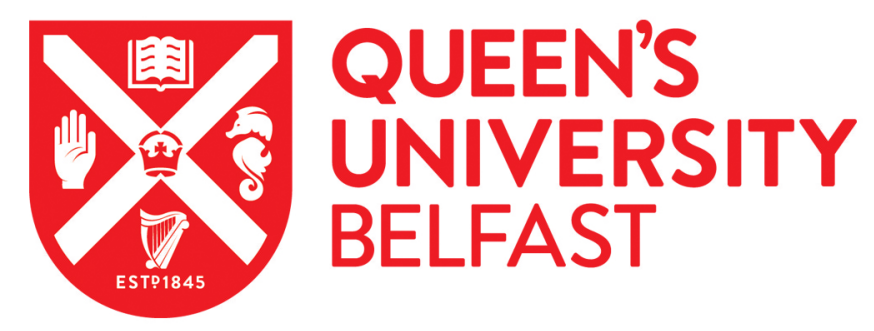

\title{
Time-Variation in the Relationship between White Precious Metals and Inflation: A Cross-Country Analysis
}

Huseyin Bilgin, M., Gogolin, F., Chi Keung Lau, M., \& Vigne, S. A. (2018). Time-Variation in the Relationship between White Precious Metals and Inflation: A Cross-Country Analysis. Journal of International Financial Markets Institutions and Money. https://doi.org/10.1016/j.intfin.2018.03.001

Published in:

Journal of International Financial Markets Institutions and Money

Document Version:

Peer reviewed version

Queen's University Belfast - Research Portal:

Link to publication record in Queen's University Belfast Research Portal

Publisher rights

Copyright 2018 Elsevier

This manuscript is distributed under a Creative Commons Attribution-NonCommercial-NoDerivs License

(https://creativecommons.org/licenses/by-nc-nd/4.0/), which permits distribution and reproduction for non-commercial purposes, provided the author and source are cited.

\section{General rights}

Copyright for the publications made accessible via the Queen's University Belfast Research Portal is retained by the author(s) and / or other copyright owners and it is a condition of accessing these publications that users recognise and abide by the legal requirements associated with these rights.

Take down policy

The Research Portal is Queen's institutional repository that provides access to Queen's research output. Every effort has been made to ensure that content in the Research Portal does not infringe any person's rights, or applicable UK laws. If you discover content in the Research Portal that you believe breaches copyright or violates any law, please contact openaccess@qub.ac.uk. 


\title{
Time-Variation in the Relationship between White Precious Metals and Inflation: A Cross-Country Analysis
}

\author{
Mehmet Huseyin Bilgin ${ }^{\mathrm{a}}$, Fabian Gogolin ${ }^{\mathrm{b}}$, Marco Chi Keung Lau ${ }^{\mathrm{c}}$, \\ Samuel A. Vigne ${ }^{\mathrm{d}}$ \\ ${ }^{a}$ Istanbul Medeniyet University, D-100 Karayolu 34732, Goztepe Kadikoy, Istanbul, \\ Turkey \\ email: mehmet.bilgin@medeniyet.edu.tr \\ ${ }^{b}$ Queen's Management School, Queen's University Belfast, BT9 5EE, Northern Ireland, \\ United Kingdom \\ email: f.gogolin@qub.ac.uk \\ ${ }^{c}$ Department of Accountancy, Finance and Economics, Huddersfield Business School, \\ University of Huddersfield, Queensgate, HD1 3DH, UK \\ email: c.Lau@hud.ac.uk \\ ${ }^{d}$ Queen's Management School, Queen's University Belfast, BT9 5EE, Northern Ireland, \\ United Kingdom \\ email: s.vigne@qub.ac.uk (corresponding author)
}

\begin{abstract}
In recent years, as a result of an increasing financialisation of financial markets, white precious metals have slowly transformed from mere production inputs to investment assets. In order to analyse the characteristics of white precious metals and the consequences of the transition, this paper examines the long-run inflation hedging effectiveness of silver, platinum, and palladium using both linear and non-linear cointegration relationship procedures. This study is the first to formally investigate the inflation hedging effectiveness of white precious metals across different countries. Overall, the results point towards the superiority of palladium as the most reliable inflation hedge. Furthermore, country-specific graphical evidence uncovers time-variation in the inflation hedging potential of white precious metals.
\end{abstract}

Keywords: White Precious Metals, Silver, Platinum, Palladium, Inflation, Hedge

JEL Code: F30; F65; G12 


\section{Introduction}

A considerable amount of research was published on the relationship between precious metals and inflation over the last few years (see O'Connor et al. (2015) and Vigne et al. (2017)), though the findings and conclusion are by no means consistent ${ }^{1}$. The theoretical underpinning for an alleged relationship between precious metals and inflation depends on the philosophical approach taken in defining what precious metals are. If precious metals are considered to be international currencies, which up until the $20^{\text {th }}$ century they were, then an increase in expected inflation should lead to investors driving down their cash holding in order to invest in precious metals, driving up their price. On the other hand, if precious metals are considered regular commodities needed as production inputs, their prices should rise alongside the prices of any other regular assets for that is the very definition of inflation (Jaffe (1989)).

Even though white precious metals in general, and platinum and palladium in particular, were usually considered to be mere production inputs, the recent introduction of a silver ETF in April 2006 and ETFs for platinum and palladium in August 2010 have substantially strengthen the investment side of the metals. Furthermore, an upwards and quite substantial trend in the physical demand for white precious metals as investment assets can be observed for all three metals over recent years (see Lau et al. (2017) for more details and figures). Historically, the golden constant has been identified as the most effective hedge against inflation, however, in more recent years, as a result of an increasing financialisation of commodity markets (see Gogolin and Kearney (2016) and Lucey et al. (2018)), white precious metals have transformed from mere production goods to actively traded securities. As investment assets, white precious metals could serve as an alternative, and

\footnotetext{
${ }^{1} \mathrm{~A}$ thorough presentation and discussion on academic findings about the gold-inflation relationship can be found in Lucey et al. (2017).
} 
maybe more effective protection against inflation.

In a recent investigation involving silver, Bampinas and Panagiotidis (2015) document a strong time-varying relationship between silver and inflation for the UK but not for the US. However, McCown and Shaw (2016) find evidence that white precious metals such as platinum and palladium offer better hedging characteristics than gold in the US between 1992 and 2015. These conflicting results call for a thorough investigation of the inflation hedging ability of white precious metals across different countries.

To take into account the transition and consequences resulting from a shift towards an investment asset, this study employs a time-varying cointegration framework to uncover whether white precious metals offer protection against inflation. We investigate the long-run dynamics of those relationships in order to compare pre- and post-transition characteristics of silver, platinum and palladium using monthly data between January 1988 and December 2016. The countries in this study have been selected based on their relative importance in the supply and demand of white precious metals. As a result the countries selected are Canada, China, Germany, Italy, Japan, Mexico, South Africa, South Korea, Switzerland, the United Kingdom, and finally, the United States of America ${ }^{2}$.

Previous research on the financial aspects of white precious metals tends to focus on trading activity (Batten et al. (2018)), or on hedging and safe haven aspects of white precious metals against debt and equity (Lucey and $\mathrm{Li}$ (2015) and Li and Lucey (2017)) more than on the hedging potential of the precious metals against consumer price inflation. In this paper, we identify the inflation hedging potential of silver, platinum and palladium against inflation rates in 11 countries. Working with the Johansen (1995) cointegration test, we identify the relationship between white precious metals and inflation, offering a sober approach to the subject and an insightful anal-

\footnotetext{
${ }^{2}$ Country-specific details can be found in The Silver Institute (2016) and Gold Field Mineral Services Ltd. (2015).
} 
ysis for investors and regulators. Furthermore, the identified cointegration relationships are tested for time-variancy in order to understand the development of a long-run positive relationship between the time series. We follow previous research on precious metals (Beckmann and Czudaj, 2013, Batten et al., 2014, Lucey et al., 2017) and offer a visualisation and an explanation of changing relationships between the series. The findings are augmented with the advanced quantile cointegration method, which are again set in a time-varying framework.

The findings point to the superiority of platinum as an effective long-term inflation hedge. While palladium is also found to be an effective inflation hedge, the relationship is dominated by short-run dynamics. In line with Bampinas and Panagiotidis (2015), silver is found to be the least effective hedge across the elven countries considered. This relationship could be explained by the predominantly industrial nature of platinum and palladium compared to silver.

The empirical results suggest that white precious metals in general, and platinum and palladium in particular, can be used as effective investment assets in inflationary environments. Despite being yield free commodities, they should be considered as candidates for a well diversified investment portfolio.

In Section 2 the literature is briefly discussed, while Sections 3 and 4 will discuss the data and the methodology respectively. Empirical results are presented in Section 5 while Section 6 concludes.

\section{Literature Review}

In comparison to the bulk of research that exists on the relationship between gold and inflation, the research focusing on the inflation hedging potential of white precious metals is limited (Vigne et al. (2017)). Taylor (1998) provides first insides in respect to the hedging ability of silver. Using the US Consumer Price Index between January 1914 and April 1996, 
the author finds that silver is both a short-run and long-run hedge against American inflation. Results for silver indicate that the metal was a long-run hedge over the entire period observed, but that silver also served as a shortrun hedge against the US CPI over many subperiods of the sample. This is particularly true during the second Organisation of Oil Exporting Countries (OPEC) crisis of 1979, but not during the first OPEC crisis of 1973.

The investigation is continued by Adrangi et al. (2003) a few years later where the authors work with monthly averages of London Fix silver prices between April 1967 and November 1999 as well as with the American Industrial Production Index (IP) and the Consumer Price Index. Results show that silver was a good hedge against inflation over the time period considered. Moreover, the authors find that the Fischer (1930) hypothesis holds, in other words, real silver returns are not adversely affected by inflation. Finally, the econometric results do not offer support in favour of the Fama (1981) proxy hypothesis.

More recently, Bampinas and Panagiotidis (2015) take into account annual data of gold and silver prices as well as consumer prices in the United Kingdom and the United States of America between 1791 and 2010; Reinhart and Rogoff (2011) provide researchers with historical inflation data going back this far. Both the linear Hodrick and Prescott (1997) filter and an asymmetric Christiano and Fitzgerald (2003) band-pass filter are used to derive expected CPI series. Bampinas and Panagiotidis (2015) are one of the few papers to look at the relationship between silver and inflation in a time-varying manner, where the methodology is based upon the Johansen (1995) cointegration framework and upgraded with a Bierens and Martins (2010) test for time-varying cointegration. For both countries, the UK and the US, silver shares no long-run relationship with inflation; however, in a time-varying framework, a strong long-run relationship does exist between silver and UK inflation. Since a time-varying relationship still fails to exist for the US, the authors conclude that silver was not an effective inflation 
hedging instrument against American inflation in the past 200 years.

McCown and Shaw (2016) investigate the relationship between platinum, palladium and inflation in the United States between 1992 and 2015. Correlation results indicate that white precious metals are a better inflation hedge than gold over the period considered. The authors go a step further and also argue that platinum is the superior foreign exchange rate hedge, akin to the alleged virtue of precious metals to function as international currencies. Results based on the safe haven methodology proposed by Baur and Lucey (2010) also indicate a strong potential of platinum to diversify away equity portfolio risks.

In light of these conflicting findings about the ability of white precious metals to hedge inflation, this study takes into account 28 years of data for a multitude of developed and developing economies and rely on linear and non-linear cointegration analyses in order to understand when and why white precious metal act as inflation hedgers.

\section{Data}

The country selection is based on the relative importance of the individual countries on either the supply and demand side (or both) of silver, platinum and palladium. Our investigation considers the previous mentioned countries. National inflation is measured through the country's official Consumer Price Index (CPI) for all countries. Recent work has highlighted the importance of unexpected inflation on the price of gold (Conlon et al. (2017)), but is based on an understood relationship between realised inflation and gold, which doesn't exist so far for white precious metals and which this paper is trying to provide. The most common white precious metal prices are used, so that the prices considered are: the Handy \& Harman US Dollar price of silver per troy ounce, the US Dollar London Platinum Free Market

price of platinum per troy ounce, and finally, the London Metal Exchange US Dollar price of palladium per troy ounce. The natural logarithm is con- 
sidered across all series and the prices of silver, platinum and palladium were converted into local currency in order to delete a possible US Dollar effect in the relationship between white precious metals and inflation. Due to data availability, the investigations ranges between January 1988 and December 2016, while a summary of the data and the relevant sources can be found in Table 1.

\section{Insert Table 1 about here}

The selection of the 11 countries is motivated through their importance on white precious metal markets and consist of a mixture of major producers, consumers, and markets. South Africa, Canada and the United States are amongst the top five global producers of both platinum and palladium (Gold Field Mineral Services Ltd. (2015)), alongside Zimbabwe and Russia, which were both omitted from this study due to data availability. The role of the United States and Canada as silver producing countries is also nonnegligible, where they rank on place 9 and 14 of the total global production scale (The Silver Institute (2016)) - despite of course being two major players on the demand side of the market. While Australia is the $5^{\text {th }}$ largest producer of silver, it is very unfortunate that only quarterly inflation figures exist for the Oceanic economy, leading to the decision of excluding the country from the investigation in order not to limit the data availability offered by the 11 other countries. The world largest producer of silver is Mexico, with 189.5 million ounces produced in 2015, considerably more than China on the third place with 109.1 million ounces (The Silver Institute (2016)); while Mexico's demand for white precious metals is not extraordinary, China has a vast demand for all three metals, mainly coming from it's industry and high economic growth rate. Other big players of industrial demand for white precious metals are Germany and the United Kingdom of Great Britain and Northern Ireland, being together the two largest European demanders of silver for industrial applications. While Italy is also a player on the industrial demand side of white precious metals, it's main importance is as the 
largest demander of silver for jewellery production, where the Italian demand stands for more than $50 \%$ of the total European silver demand (The Silver Institute (2016)). A very different picture is seen for Japan, where nearly the entirety of silver demand is industrial. Another Asian economy with a large demand for silver in industrial applications is South Korea, though the country is somewhat active as a jewellery producer as well. Switzerland is an interesting actor on the silver market, while it's role on both the supply and demand side is relatively unimportant, the European country is home to $13 \%$ of global ETP holdings, and alongside the United Kingdom, the major trading centre for both platinum and palladium.

\section{Methodology}

The long-run inflation hedging potential of white precious metals against inflation can be specified in the following equation using the generalised Fisher effect framework:

$$
W P M_{t}=\alpha+\beta C P I_{t}+\mu_{t}
$$

Where $W P M_{t}$ stands for the natural logarithms of silver, platinum and palladium prices respectively, while $C P I_{t}$ stands for the natural logarithm of consumer prices; $\mu_{t}$ is the error term of the process. The cointegration coefficient of regressors $\beta$ denotes the long-run elasticity of white precious metal prices with respect to inflation, illustrating the percentage change in white precious metal prices for every $1 \%$ change in the level of inflation. Superior hedge performance implies $\beta>1$, while full hedge performance implies $\beta=1$ and partial hedge performance implies $0<\beta<1$.

\subsection{Time-Varying Vector Error Correction Model}

Johansen $(1991,1995)$ proposes the error correction form of a given VAR model of $I(1) X^{\prime} s$ :

$$
\Delta X_{t}=\sum_{j=1}^{p-1} \Phi_{j} \Delta X_{t-j}+\Pi X_{t-1}-\gamma_{0}-\gamma_{1} t+\varepsilon_{t}, \quad \varepsilon_{t} \sim N_{k}(0, \Omega)
$$


where $X_{t}$ is a $k * 1$ vector of the variables observed at time $t=1, \ldots, T$. Furthermore, $\Omega$ and $\Phi_{j}$ are $k * k$ matrices with $j=1, \ldots, p-1$, while $\gamma_{0}$ and $\gamma_{1}$ are both the respective $k * 1$ vectors of the VECM's intercepts and linear trend coefficients.

Bierens and Martins (2010) propose a time-varying VECM of order $p$ in which the cointegrating vectors are smooth functions of time and that for some $t$ there are fixed $r<k$ linearly independent columns of the timevarying $k * r$ matrix $\beta_{t}=\left(\beta_{1 t}, \ldots, \beta_{r t}\right)$ :

$$
\Delta X_{t}=\sum_{j=1}^{p-1} \Phi_{j} \Delta X_{t-j}+\alpha \beta_{t}^{\prime} X_{t-1}+\gamma_{0}+\varepsilon_{t}, \quad t=1, \ldots, T
$$

In the above equation, $\varepsilon_{t} \sim N_{k}(0, \Omega)$, $\alpha$, is a fixed $k * r$ matrix (with $r$ representing the cointegrating rank of the system), and $\beta_{t}$ is a time-varying $k * r$ matrix with rank $r$. The null hypothesis of time-invariant cointegration $\left(\Pi_{t}^{\prime}=\Pi^{\prime}=\alpha \beta_{t}^{\prime}\right)$ is tested against the alternative hypothesis of time-varying cointegration of the type $\Pi_{t}^{\prime}=\alpha \beta_{t}^{\prime}$. $\Omega$ and $\Phi_{j}$ are $k * k$ matrices while $T$ stands for the number of observations.

Assuming standard smoothness and orthonormality conditions, Bierens and Martins (2010) argue that the parameters of vector $\beta_{t}$ can be approximated by a finite sum of Chebyshev time polynomials $P_{i, T}(t)$ of decreasing smoothness for some fixed $m$ :

$$
\beta_{t}=\beta_{m}(t / T)=\sum_{i=0}^{m} \xi_{i, T} P_{i, T}(t), \quad t=1, \ldots, T
$$

where $1 \leq m<T-1 . \xi_{i, T}=\frac{1}{T} \sum_{t=1}^{T} \beta_{T} P_{i, T}(t)$ for $i=0, \ldots, T-1$ are unknown $k * r$ matrices.

By substituting Equation 4 into Equation 3, the following is obtained:

$$
\Delta X_{t}=\sum_{j=1}^{p-1} \Phi_{j} \Delta X_{t-j}+\alpha \xi^{\prime} X_{t-1}^{(m)}+\gamma_{0}+\varepsilon_{t},
$$

where $\xi^{\prime}=\left(\xi_{0}^{\prime}, \xi_{1}^{\prime}, \ldots, \xi_{m}^{\prime}\right)$ is an $r *(m+1) k$ matrix of rank $r$ and $X_{t-1}^{(m)}$ 
is defined by

$$
X_{t-1}^{(m)}=\left(X_{t-1}^{\prime}, P_{1, T}(t) X_{t-1}^{\prime}, P_{2, T}(t) X_{t-1}^{\prime}, \ldots, P_{m, T}(t) X_{t-1}^{\prime}\right)^{\prime}
$$

where the null hypothesis of time-invariant cointegration corresponds to

$\xi^{\prime}=\left(\beta^{\prime}, O_{r, k . m}\right)$, so that $\xi^{\prime} X_{t-1}^{(m)}=\beta^{\prime} X_{t-1}^{(m)}$, with $X_{t-1}^{(0)}=X_{t-1}$ and can be tested with a likelihood ratio test ${ }^{3}$.

\subsection{Quantile Cointegration Analysis}

Following Xiao (2009), we examine the relationship between white precious metals and consumer price indices across the quantiles in the conditional distribution and investigate if the relationship follows a time-varying process. This approach augments the findings of the Bierens and Martins (2010) procedure proposed earlier by examining the entire distribution of white precious metal prices as well as the time-varying cointegration coefficients. The long-run equilibirum between two time series can be estimated with the following equation including lead-lag terms:

$$
W P M_{t}=\alpha+\beta_{t}^{\prime} C P I_{t}+\sum_{j=-n}^{n} \Delta C P I_{t-j}^{\prime} \Psi_{j}+\mu_{t}
$$

Given that $Q_{\mu}(\tau)$ with $\Phi_{t}=\sigma\left\{C P I_{t}, \Delta C P I_{t}, \forall j\right\}$ can be used to denote the $\tau^{\prime}$ th quantile of $\mu_{t}$, conditional on $\Phi_{t}$, the $\tau^{\prime}$ th quantile of $W P M_{t}$ is given by:

$$
Q_{W P M_{t}}\left(\tau \mid \Phi_{t}\right)=\alpha+\beta(\tau)^{\prime} C P I_{t}+\sum_{j=-n}^{n} \Delta C P I_{t-j}^{\prime} \Psi_{j}+\Pi_{\mu}^{-1}(\tau)
$$

Where $\Pi_{\mu}^{-1}(\tau)$ is the cumulative density function of $\mu_{t}$ and Equation 7 can be rewritten as:

$$
W P M_{t}=\Theta(\tau)^{\prime} Z_{t}
$$

\footnotetext{
${ }^{3}$ More details about the application of the Bierens and Martins (2010) procedure can be found in Bampinas and Panagiotidis (2015) and in Lucey et al. (2017).
} 
while Equation 8 becomes:

$$
Q_{W P M_{t}}\left(\tau \mid \Phi_{t}\right)=\Theta(\tau)^{\prime} Z_{t}
$$

Where $Z_{t}$ is the vector of regressors including $\left(1, C P I_{t}\right)$ and $\left(\triangle C P I_{t-j}^{\prime}, j=\right.$ $-n, \ldots, n)$. Furthermore, $\Theta=\left(\alpha, \beta_{t}^{\prime}, \Psi_{-n}^{\prime}, \ldots, \Psi_{n}^{\prime}\right)^{\prime}$, and $\Theta(\tau)=\left(\alpha(\tau), \beta(\tau)^{\prime}, \Psi_{-n}^{\prime}, \ldots, \Psi_{n}^{\prime}\right)^{\prime}$ while $\alpha(\tau)=\alpha+\Pi_{\mu}^{-1}(\tau)$.

Time-variation behaviour of the cointegration vector $\beta_{t}$ can be tested by means of the Kolgomorov-Smirnov statistic $\sup _{\tau}\left|\hat{V}_{T}(\tau)\right|$, where $\hat{V}_{T}(\tau)=$

$T(\hat{\vartheta}(\tau)-\hat{\vartheta})$. Note that $\vartheta=\beta^{\prime}$, and $\hat{\vartheta}(\tau)$ is the quantile estimator from Equation 8 and $\hat{\vartheta}$ is a T-consistent estimator of $\vartheta$. Finally, the $\sup _{\tau}\left|\hat{\vartheta}_{T}(\tau)\right|$ statistic has a non-standard asymptotic distribution while re-sampling methods are used to generate critical values.

\section{Empirical Results}

\subsection{Cointegration Results}

The Augmented Dickey Fuller procedure is applied to every series and results indicate that all the time series are non-stationary and possess a unit root (Table 2).

\section{Insert Table 2 about here}

The Johansen test results are displayed in Tables $3 \mathrm{a}$ and $3 \mathrm{~b}$ and reveal interesting findings for all the different countries.

\section{Insert Tables $\mathbf{3 a}$ and $\mathbf{3 b}$ about here}

Both platinum and palladium are cointegrated with inflation in Canada, but silver fails to be. Indeed, while the importance of Canada is relatively weak as a silver producing country, Canada is an important producer of both platinum and palladium, a reason which could explain the observed relationship. 
Regarding China, none of the three white precious metal are found to have a long-run cointegration relationship with inflation. Concerning silver and platinum, results indicate that no long-run relationship with inflation exists; results different to those observed for palladium, where two cointegration vectors indicate stochastic movements in the relationship pointing towards short-term co-movements between the series. Indeed, the results found for the relationship between palladium and inflation in China call for a more detailed investigation into the short-term drivers of the cointegration relationship which is provided later on.

In Germany, all three precious metals are cointegrated with inflation and served as a hedge against inflation over the past 30 years. The demand for white precious metals in Germany is very large on a Global scale, mainly in the light that the demand for platinum and palladium in Germany is fueled by a growing and strengthening vehicle production which is about one third of the total European production (Gold Field Mineral Services Ltd. (2015)). An identical finding is observed for Italy and South Korea, two other industrial Nations where the prices of silver, platinum and palladium were cointegrated with inflation over the past 30 years.

Considering the results of three other industrialised countries, namely Japan, the United Kingdom of Great Britain and Northern Ireland, and the United States of America, results point towards the ability of silver and platinum to hedge inflation, but also towards stochastic elements in the relationship between palladium and the three national inflation measures.

South Africa is a Global player on the supply market of both platinum and palladium while Mexico is the globally leading producer of silver. In both countries, all three white precious metals served as hedging instruments against inflation between 1988 and 2016.

Finally, results for Switzerland indicate that while platinum is a long-run hedge against inflation, the relationship for silver and palladium is somewhat more complex and should be considered more carefully. 


\subsection{Time-Variation and Quantile Cointegration}

According to Table 4, time-variation is identified in the cointegration relationship between all white precious metals and inflation indices, pointing towards trends and seasonalities of the series.

\section{Insert Table 4 about here}

A country level quantile cointegration analysis between white precious metal prices and inflation rates is conducted next. We examine the hedging performance at different points of the conditional distribution of metal prices; the methodology of Xiao (2009) takes into account time varying cointegrating coefficients and estimates the cointegrating coefficient at different quantiles of the conditional estimation of metal prices for each country.

Table 5 reports the results of the stability test, and the $\sup _{\tau}\left|\hat{V}_{T}(\tau)\right|$ statistic shows that most of the results provide evidence that the long-run relationships are not constant over time, except for the case of palladium in China - where stochastic elements driving the relationship where identified by the Johansen (1995) procedure.

\section{Insert Table 5 about here}

Table 6 presents the country-specific quantile cointegrating regression results and it can be seen, that the coefficients are statistically significant for the majority of the countries across quantiles. Overall, the quantile regressions lend support to the hedging relationship between white precious metals and inflation; and it is interesting to note that the occurrence of a cointegrating relationship increases at higher quantiles, such as $\tau=0.75$ and $\tau=0.90$, for platinum in China. Further evidence seems to indicate that some metals have no hedging effectiveness against inflation (for example silver in China, Italy, Japan, Mexico, and South Korea; or palladium in Italy, Mexico, and South Africa), results in contrast to those obtained through a Johansen cointegration procedure (Tables $3 \mathrm{a}$ and $3 \mathrm{~b}$ ). Furthermore, it is 
suggested that the most superior hedge performance is the palladium market in Switzerland while the lowest partial hedge performance is the platinum market in China.

\section{Insert Table 6 about here}

Finally, when considering the effectiveness of the different white precious metals in comparison to one another, it is evident that platinum ranks first in terms of the number of significant cointegrating relationship at the $1 \%$ significant level, followed by palladium and silver - indeed, we observe that platinum has the highest percentage of superior hedge performance $(82 \%)$, followed by palladium (64\%) and silver (45\%).

\subsection{Variation in long-run Relationships}

Somewhat conflicting results are delivered by the two cointegration methodologies presented above and call for a formal and consolidating countryspecific investigation into the true nature of the relationship between white precious metals and inflation. Indeed, an important issue that remains to be addressed is when and how the long-run relationship between the series changed.

The scaled trace statistic of Johansen's cointegration procedure is extracted for every series and plotted over time, allowing for a visualisation of the evolving relationship between white precious metals and inflation, ultimately revealing when silver, platinum and palladium served as hedges against inflation across the 11 different countries.

\section{Insert Figure 1 about here}

In Canada, palladium was the most reliable hedge against inflation throughout the period considered, though silver also proved to be a somewhat effective hedge over certain time periods. Two things should be noted when explaining the superiority of palladium against platinum. First of all, Canada's 
relative importance as a supplier of palladium is more important than as a supplier of platinum, and second, Canada's demand for palladium as a production factor for catalysts is much stronger than that for platinum. It is noteworthy to mention that silver was a surprisingly good hedge against inflation in Canada, except for a short period between 2000 and 2006, even though the two series don't share a formal long-run relationship (Table 3a). It seems however, that while the demand for silver in Canada is relatively low compared to other countries, the important chronological increase in physical silver demand as an investment asset was beneficial for silver's ability to hedge Canadian inflation. Around 2008, a break in the cointegration relationship between platinum and Canadian inflation can be observed. An explanation can be found in the strong fall in price of the white precious metal between 2008 and 2009 and the continuous decrease in Canadian mine production for platinum to approximately half the level of 2008 in the year 2010 (Gold Field Mineral Services Ltd. (2016)).

In conclusion, it can be said that while silver proved to be a surprisingly effective hedging instrument against inflation in Canada, palladium was by far the most effective inflation hedge of the three white precious metals considered. The driving force behind the hedging relationship of platinum and palladium with Canadian inflation seems to stem from mining activities, while the gradual shift towards using silver as an investment asset was beneficial for the metals inflation-hedging abilities.

\section{Insert Figure 2 about here}

In China, the striking observation is similar to that made for Canada, where it seems that palladium is the most reliable hedging instrument against inflation. The trend for all three precious metals is that they became effective inflation hedgers over time, starting around the late 1990s for platinum and palladium, and around the mid 2000s for silver. A break in cointegration between platinum and Chinese inflation is indicated around the global financial crisis; pointing towards the relative superiority of silver and especially 
palladium to act as hedging instruments. Silver starts to be cointegrated with inflation in China when the industrial demand for silver strongly grows in line with silver linked industrial activities (The Silver Institute (2008)); a similar story is observed for platinum in China, where industrial demand for platinum starts picking up in the late 1990s (Johnson Matthey (2017)). Of the three white precious metals considered, palladium was the most reliable inflation hedge starting only around 1998, results in line with the stochastic elements indicated by the Johansen (1995) procedure and suggesting that the distribution of the different quantiles are pooled in the bipolar tails of the sample. Again, the start of a cointegration relationship with inflation occurs in line with the beginning of a period of growing demand for palladium as an industrial production input (Johnson Matthey (2017)).

In China, the inflation hedging ability of white precious metals is a reaction to their growing importance in industrial applications; similarly to what is observed in Canada, palladium was the most effective inflation hedging instrument of the three white precious metals.

\section{Insert Figure 3 about here}

In Germany, a trend away from cointegration can be observed over time for all three white precious metals considered. However, similarly to what is observed for Canada and China, palladium proved to have been the most reliable investment to hedge inflation over the past 30 years. Furthermore, the detrimental impact of the global financial crisis on the relationship between platinum and inflation can again be observed. However, in stark contrast to what is observed for Canada and China, the recent crisis was also detrimental to the relationship between silver and consumer price inflation in Germany. So while silver indeed has a considerable track record as an investment asset in Germany, a formal investigation uncovers that palladium is the more attractive inflation hedge out of the three precious metals considered. The break in the cointegration relationship between silver and German inflation around 2009 is in line with a downturn in physical 
silver demand as a reaction to a lesser importance of the precious metal in industrial applications and as an investment asset. The German car market accounts for approximately one-third of European vehicle production, and while both platinum and palladium can be used in the production of diesel and gasoline engines, a decreasing importance of platinum to the benefit of palladium can be noticed over the past decade (The Silver Institute (2016)). So while the three precious metals were cointegrated with German inflation during the beginning of the sample, pushed by their importance as industrial production factors in the automobile industry for platinum and palladium, and notably in the photographic industry for silver, a decreasing industrial demand for silver and platinum led to a break in the relationship with inflation. On the other hand, the gradual shift away from using platinum as a production factor in the automobile industry has strengthen the abilities of palladium to act as an inflation-hedger.

Results for Germany are similar to those obtained for China, where industrial application is the main driving force behind a possible inflationhedging ability. In line with results obtained for Canada and China, the superiority of palladium as an inflation-hedge is revealed.

\section{Insert Figure 4 about here}

In Italy, results indicate that white precious metals were inefficient inflation hedges and that the positive long-run relationship with inflation is driven by the early part of the sample. Indeed, silver, platinum, and palladium only acted as a hedge until mid-1998, and offered no protection against inflation ever since; urging investors to reconsider investing in silver, platinum, and palladium as a hedge against inflation. Results for Italy are very insightful as the break in relationship between the three white precious metals and national inflation is not in line with a slowing demand per se; furthermore, the fact that Italy is the second global producer of silver jewellery after India (The Silver Institute (2016)) doesn't seem to play a role on the metals inflation-hedging potential. 
So while the relationship between white precious metals and inflation in Italy doesn't depend on changes in the demand for any of the metals, it can be concluded that none of the metals are attractive hedging instruments against inflation due to underlying inflation dynamics in the country.

\section{Insert Figure 5 about here}

A somewhat similar story is observed in Japan, where all three white precious metals stop to be cointegrated with inflation around the late 1990s, early 2000s - similar results for gold are observed by Lucey et al. (2017).

A likely explanation can be found in the period of deflation the Japanese economy was going through over the past decades, but also in the stagnating economic activities of the country - results similar to those obtained for Italy, where a break in the relationship between white precious metal prices and inflation is also observed. While a downturn in the demand for silver in Japan can only really be observed towards the end of the sample, the drop in demand for platinum around the late 1990s is in line with the observed break in Figure 5. Results in Japan are in stark contrast to those observed for Germany, a comparably strong producer of vehicles driving the industrial demand for platinum and palladium. Indeed, while the Japanese demand for palladium was growing considerably over the 2000s (Johnson Matthey (2017)), the metal never offered a protection against inflation; akin to the more complex nature of inflation rates in Japan, that was going through periods of deflation during the past three decades.

While Japan is one of the most industrial countries in the sample and has had a record of considerable demand for the three precious metals over the period considered, none of the three white precious metals considered offer a reliable refuge against inflation; pointing towards the detrimental effects of deflationary episodes on inflation-hedging abilities of precious metals (Hoang et al. (2016)).

\section{Insert Figure 6 about here}


Results for Mexico are in line with those obtained for Canada, China, and Germany: palladium is the superior inflation hedge across all three white precious metals considered. Indeed, palladium and the Mexican CPI were cointegrated throughout nearly the entire sample, while platinum goes in and out of inflation hedging phases. While Mexico is a very important producer of silver, a break in cointegration is identified around the mid 2000s, indicating that changes in mining activities are not as important in Mexico as they are in Canada.

The insightful results for Mexico reveal palladium as the most reliable hedging instrument over the time period considered, while the relationship with both silver and platinum breaks around 2004 - indicating that mining activity is not the driving force of inflation hedging potential in the North American economy.

\section{Insert Figure 7 about here}

The relative superiority of silver and palladium as inflation hedges is again observed in South Africa, where the two metals were cointegrated with the CPI during the early part of the sample. Considering silver, the slow shift upwards of the trace statistic is in line with a steady decrease of silver mine production over the past decades (The Silver Institute (2016)). Indeed, the African country only produced about $40 \%$ of the silver quantity in 2015 compared to 2006, the year where silver isn't cointegrated with inflation any longer. South Africa is the world's biggest producer of platinum and also a global leader in the production of palladium. However, the inflation-hedging capacities of platinum are scare to say the least; palladium only hedged inflation during the first part of the sample. While a formal reasoning can't be found on the supply side of the two precious metals, a possible explanation might be found in the underlying economy rather than in price movements of the white precious metals per se. Indeed, it could be the importance of white precious metals as exports of the South African economy; here the argument is that the exposure to international metal prices is a driver of 
national inflation and therefore, that the relationship between the metals and the inflation rate is more complex than for other countries.

In South Africa, silver proved to have been the relatively most reliable inflation hedge in comparison to platinum and palladium. So while South Africa is an important producer of both metals, they did not serve as effective hedges against rising prices in the African economy.

\section{Insert Figure 8 about here}

In South Korea, palladium is by far the most superior inflation-hedging instrument out of the three white precious metals considered. While short cointegration breaks can be observed around the mid 1990s and early 2000s, palladium was comfortably cointegrated with South Korean inflation rates up until 2013. So while the East Asian economy is home to an important economy, and notably an important automotive industry, silver and platinum were not very effective inflation hedges over the past 30 years. However, similarly to Germany, another important car producing economy, palladium was the most effective cointegration hedge over the entire sample.

A similar pattern to Germany is observed for South Korea, were palladium was the most effective inflation hedge over the period considered. This offers further evidence for the detrimental effects of deflation and disinflation in Japan, were one would indeed expect hedging potential of palladium, in the light of the importance of the automotive industry in the country.

\section{Insert Figure 9 about here}

Switzerland is, alongside the United Kingdom, one of the two major trading centres for paltinum and palladium bullion (Gold Field Mineral Services Ltd. (2015)), while the importance of Switzerland on the silver market has been declining over the past few years (The Silver Institute (2016)), with countries facing a decline of the amount of silver held nationally. The relationship between white precious metals and inflation is telling a similar 
story, with silver being the weakest metal to hedge inflation. Again, palladium proves to be the most reliable inflation hedge, though it stopped around the recent global financial crisis of 2008.

In Switzerland, the importance of the country as a trading centre seems to be the decisive element in explaining the relationship between white precious metals and inflation. Indeed, while Switzerland is a key player on the platinum and palladium market, the importance of the domestic market for silver diminished over the past years, probably explaining why silver was not a reliable inflation hedge. Considering palladium however, while the metal was the best inflation hedge, this relationship stopped around 2008 .

\section{Insert Figure 10 about here}

In the United Kingdom, white precious metals were surprisingly ineffective in hedging inflation. While some evidence of cointegration is found for silver and palladium in the beginning of the sample, a break in cointegration for all series with the CPI is observed around the early 2000's. The difference in dynamics between precious metals and inflation series is in contrast to the findings of Lucey et al. (2017), who formally investigate the longrun relationship between gold and the UK CPI and provides evidence for long-term cointegration between the series, that only breaks around 2009 .

It therefore seems that gold is a far more reliable inflation hedge in the United Kingdom compared to white precious metals (Lucey et al. (2017)). While the United Kingdom is home to an important trade centre for precious metals in general, despite being also an important player on the demand side, it seems that the inflation dynamics of the country rather co-move with gold, which official price is being fixed in London since 1919.

\section{Insert Figure 11 about here}

Results for the United States of America are very revealing and uncover the superiority of palladium as a white precious metal hedging consumer price inflation. Indeed, palladium was cointegrated with the US CPI 
throughout the sample, except for a few short periods. Silver and platinum on the other hand prove themselves to be quite unreliable hedging instruments, though the United States are a very important player on the demand side of both precious metals.

Results for the United States reveal the hedging superiority of palladium, the most industrial of the three precious metals. Interestingly, silver is found to be a very weak inflation hedging instrument, showing again that gold is the precious metal capable of offer protection to investors, rather than silver (Lucey et al. (2017)).

\section{Conclusion}

This study provides insights into the relationship between white precious metals and inflation. The research is motivated by a lack of a detailed investigation, the apparent transition from industrial input to investment assets and the recent introduction of ETFs for all three white precious metals. Thereby allowing individual and institutional investors to better exploit the investment characteristics of silver, platinum, and palladium.

Covering a 28 year period across eleven countries, the study finds that platinum is the most effective long-term hedge. Whereas the inflation hedging abilities of palladium are expressed through short-term dynamics. While many former studies investigate the inflation-hedging potential of gold (see Batten et al. (2014), Hoang et al. (2016), or Lucey et al. (2017)) and silver (Bampinas and Panagiotidis (2015)), none have formally investigated the relationship between platinum, palladium, and inflation. Findings suggest that platinum and palladium are more reliable inflation hedges because of their industrial nature, while silver, the metal with the most precious attributes to it is not very effective in this regard.

The empirical findings have important policy and investment implications, as investors view the commodity market as an attractive asset class to diversify traditional portfolios of stocks and bonds. Our findings indicate 
that platinum and palladium outperform silver in an inflationary environment, thereby qualifying the two white precious metals as potential alternatives to classical inflation hedgers and also tools to further diversify an investment portfolio.

Future research can build upon these findings and uncover the relationship between unexpected inflation and white precious metals (Conlon et al. (2017)), and derive safe haven properties of silver, platinum, and palladium based on quantile regressions (Baur and Lucey (2010) and Lucey and Li (2015)). 


\section{References}

Adrangi, B., A. Chatrath, and K. Raffiee (2003). Economic Activity, Inflation, and Hedging: The Case of Gold and Silver Investments. The Journal of Wealth Management 6(2), 60-77.

Bampinas, G. and T. Panagiotidis (2015). Are gold and silver a hedge against inflation? A two century perspective. International Review of Financial Analysis 41, 267-276.

Batten, J. A., C. Ciner, and B. M. Lucey (2014, sep). On the Economic Determinants of the GoldInflation Relation. Resources Policy 41, 101108.

Batten, J. A., B. M. Lucey, F. McGroarty, M. Peat, and A. Urquhart (2018). Does intraday technical trading have predictive power in precious metal markets? Journal of International Financial Markets, Institutions and Money 52, 102-113.

Baur, D. G. and B. M. Lucey (2010, may). Is Gold a Hedge or a Safe Haven? An Analysis of Stocks, Bonds and Gold. The Financial Review 45(2), $217-229$.

Beckmann, J. and R. Czudaj (2013, jan). Gold as an inflation hedge in a time-varying coefficient framework. The North American Journal of Economics and Finance 24, 208-222.

Bierens, H. J. and L. F. Martins (2010). Time-varying cointegration. Econometric Theory 26(5), 1453-1490.

Christiano, L. J. and T. J. Fitzgerald (2003). The Band Pass Filter. International Economic Review 44(2), 435-465.

Conlon, T., B. M. Lucey, and G. S. Uddin (2017). Is gold a hedge against inflation? A wavelet time-scale perspective. Review of Quantitative Finance and Accounting Forthcomin. 
Dickey, D. A. and W. A. Fuller (1979). Distribution of the Estimates for Autoregressive Time Series with a Unit Root. Journal of th American Statistical Association 74(366), 427-431.

Fama, E. F. (1981). Stock Returns, Real Activity, Inflation, and Money. The American Economic Review 71(4), 545-565.

Fischer, I. (1930). The Theory of Interest: Chapter 1.

Gogolin, F. and F. Kearney (2016). Does speculation impact what factors determine oil futures prices? Economics Letters 144, 119-122.

Gold Field Mineral Services Ltd. (2015). GFMS Platinum \& Palladium survey 2015.

Gold Field Mineral Services Ltd. (2016). GFMS Platinum Group Metals Survey.

Hoang, T. H. V., A. Lahiani, and D. Heller (2016). Is gold a hedge against inflation? New evidence from a nonlinear ARDL approach. Economic Modelling 54, 54-66.

Hodrick, R. J. and E. C. Prescott (1997). Postwar US business cycles: an empirical investigation. Journal of Money, Credit and Banking, 1-16.

Jaffe, J. F. (1989). Gold and Gold Stocks as Investments for Institutional Portfolios. Financial Analysts Journal 45(2), 53-59.

Johansen, S. (1991). Estimation and Hypothesis Testing of Cointegration Vectors in Gaussian Vector Autoregressive Models. Econometrica 59(6), $1551-1580$.

Johansen, S. (1995). Likelihood-Based Inference in Cointegrated Vector Autoregressive Models. New York: Oxford University Press.

Johnson Matthey (2017). Market Data Tables. 
Lau, M. C. K., S. A. Vigne, S. Wang, and L. Yarovaya (2017). Return Spillovers Between White Precious Metal ETFs: The Role of Oil, Gold, and Global Equity. International Review of Financial Analysis 52, 316332.

Li, S. and B. M. Lucey (2017). Reassessing the role of precious metals as safe havens-What colour is your haven and why? Journal of Commodity Markets 7(January), 1-14.

Lucey, B. M. and S. Li (2015). What precious metals act as safe havens, and when? Some US evidence. Applied Economics Letters 22(1), 35-45.

Lucey, B. M., S. S. Sharma, and S. A. Vigne (2017). Gold and inflation(s) A time-varying relationship. Economic Modelling 67, 88-101.

Lucey, B. M., S. A. Vigne, L. Ballester, L. Barbopoulos, J. Brzeszczynski, O. Carchano, N. Dimic, V. Fernandez, F. Gogolin, A. González-Urteaga, J. W. Goodell, P. Helbing, R. Ichev, F. Kearney, E. Laing, C. J. Larkin, A. Lindblad, I. Lončarski, K. C. Ly, M. Marinč, R. J. McGee, F. McGroarty, C. Neville, M. O'Hagan-Luff, V. Piljak, A. Sevic, X. Sheng, D. Stafylas, A. Urquhart, R. Versteeg, A. N. Vu, S. Wolfe, L. Yarovaya, and A. Zaghini (2018). Future directions in international financial integration research - A crowdsourced perspective. International Review of Financial Analysis 55, 35-49.

McCown, J. R. and R. Shaw (2016). Investment potential and risk hedging characteristics of platinum group metals. The Quarterly Review of Economics and Finance.

O'Connor, F. A., B. M. Lucey, J. A. Batten, and D. G. Baur (2015). The financial economics of gold - A survey. International Review of Financial Analysis 41, 186-205.

Reinhart, C. M. and K. S. Rogoff (2011). From Financial Crash to Debt Crisis. The American Economic Review 101, 1676-1706. 
Taylor, N. J. (1998). Precious metals and inflation. Applied Financial Economics 8(2), 201-210.

The Silver Institute (2008). World Silver Survey 2008.

The Silver Institute (2016). World Silver Survey 2016.

Vigne, S. A., B. M. Lucey, F. A. O'Connor, and L. Yarovaya (2017). The financial economics of white precious metals - A survey. International Review of Financial Analysis 52, 292-308.

Xiao, Z. (2009). Quantile cointegrating regression. Journal of Econometrics $150(2), 248-260$. 
Table 1: Data Sources used in the Study

\begin{tabular}{ll}
\hline Precious metals & Source \\
\hline Silver Handy \& Harman (Ney York) & USD/Troy ounce \\
Platinum London Metal Exchange & USD/Troy ounce \\
Palladium London Metal Exchange & USD/Troy ounce \\
& \\
Countries & Inflation Data \\
\hline Canada & CANSIM - Statistics Canada \\
China & National Bureau of Statistics of China \\
Germany & Federal Statistical Office, Germany \\
Italy & Istat - National Institute of Statistics, Italy \\
Japan & Ministry of Internal Affairs and Communications, Japan \\
Mexico & INEGI - Instituto Nacional de Estadistica, \\
& Geografia e Informatica, Mexico \\
South Africa & Statistics South Africa \\
South Korea & KOSTAT - Statistics Korea \\
Switzerland & FSO - Federal Statistical Office, Switzerland \\
United Kingdom & ONS - Office for National Statistics, United Kingdom \\
United States & Bureau of Labor Statistics, U.S. Department of Labor \\
\hline
\end{tabular}


Table 2: Augmented Dickey Fuller Unit Root Test Results

\begin{tabular}{lcccc}
\hline & Silver & Platinum & Palladium & CPI \\
\hline Canada & $-2.725^{* * *}$ & $-2.490^{* * *}$ & $-1.942^{* * *}$ & $-3.519^{*}$ \\
China & $-2.400^{* * *}$ & $-1.809^{* * *}$ & $-2.135^{* * *}$ & $-2.406^{* * *}$ \\
Germany & $-2.525^{* * *}$ & $-2.268^{* * *}$ & $-1.981^{* * *}$ & $-2.181^{* * *}$ \\
Italy & $-2.507^{* * *}$ & $-2.328^{* * *}$ & $-1.977^{* * *}$ & $2.885^{* * *}$ \\
Japan & $-2.485^{* * *}$ & $-2.163^{* * *}$ & $-2.333^{* * *}$ & $-3.712^{*}$ \\
Mexico & $-2.380^{* * *}$ & $-1.723^{* * *}$ & $-1.829^{* * *}$ & $-1.446^{* * *}$ \\
South Africa & $2.813^{* * *}$ & $-2.237^{* * *}$ & $-1.883^{* * *}$ & $-3.928^{*}$ \\
South Korea & $-2.731^{* * *}$ & $-1.887^{* * *}$ & $-1.938^{* * *}$ & $-1.690^{* * *}$ \\
Switzerland & $-2.406^{* * *}$ & $-1.830^{* * *}$ & $-2.066^{* * *}$ & $-3.008^{* * *}$ \\
United Kingdom & $-2.201^{* * *}$ & $-2.251^{* * *}$ & $-2.116^{* * *}$ & $-3.525^{*}$ \\
United States & $-2.162^{* * *}$ & $-1.763^{* * *}$ & $-2.315^{* * *}$ & $-2.213^{* * *}$ \\
\hline
\end{tabular}

Note: We report the Test Statistic of the Dickey and Fuller (1979) test where $* * *, * *$ and $*$ denotes failure to reject the the null unit root hypothesis at the $1 \%, 5 \%$ and $10 \%$ level respectively. 
Table 3a: Johansen Cointegration Test Results

\begin{tabular}{|c|c|c|c|c|c|c|c|c|c|c|c|}
\hline Country & Metal & $\begin{array}{l}\text { Max. } \\
\text { Rank }\end{array}$ & LL & & $\begin{array}{c}\text { Trace } \\
\text { Statistic }\end{array}$ & Country & Metal & $\begin{array}{l}\text { Max. } \\
\text { Rank }\end{array}$ & LL & & $\begin{array}{c}\text { Trace } \\
\text { Statistic }\end{array}$ \\
\hline & & 0 & $1,866.4685$ & . & $25.2116^{*}$ & & & 0 & $2,027.0531$ & & 60.1964 \\
\hline & Silver & 1 & $1,876.1781$ & 0.05473 & 5.7922 & & Silver & 1 & $2,054.5488$ & 0.14734 & $5.2049 *$ \\
\hline & & 2 & $1,879.0742$ & 0.01665 & & & & 2 & $2,057.1513$ & 0.01497 & \\
\hline \multirow{9}{*}{ Canada } & \multirow{3}{*}{ Platinum } & 0 & $1,953.6599$ & . & 30.6545 & \multirow{3}{*}{ Italy } & \multirow{3}{*}{ Platinum } & 0 & $2,105.5650$ & & 98.3713 \\
\hline & & 1 & $1,966.0403$ & 0.06945 & $5.8938^{*}$ & & & 1 & $2,151.9287$ & 0.23509 & $5.6440 *$ \\
\hline & & 2 & $1,968.9872$ & 0.01699 & & & & 2 & $2,154.7507$ & 0.01618 & \\
\hline & \multirow{3}{*}{ Palladium } & 0 & $1,788.6496$ & . & 26.1954 & & \multirow{3}{*}{ Palladium } & 0 & $1,961.6789$ & & 50.1703 \\
\hline & & 1 & $1,799.0233$ & 0.05853 & $5.4480^{*}$ & & & 1 & $1,984.4779$ & 0.12381 & $4.5722^{*}$ \\
\hline & & 2 & $1,801.7473$ & 0.01571 & & & & 2 & $1,986.7640$ & 0.01317 & \\
\hline & \multirow{3}{*}{ Silver } & 0 & $1,581.4894$ & . & $14.6206^{*}$ & & \multirow{3}{*}{ Silver } & 0 & $1,836.6138$ & & 19.3539 \\
\hline & & 1 & $1,587.6826$ & 0.03537 & 2.2341 & & & 1 & $1,845.9727$ & 0.05296 & $0.6362 *$ \\
\hline & & 2 & $1,588.7997$ & 0.00647 & & & & 2 & $1,846.2907$ & 0.00185 & \\
\hline \multirow{9}{*}{ China } & \multirow{3}{*}{ Platinum } & 0 & $1,656.9390$ & . & $13.4134^{*}$ & \multirow{3}{*}{ Japan } & \multirow{3}{*}{ Platinum } & 0 & $1,910.9172$ & & 20.4459 \\
\hline & & 1 & $1,661.2681$ & 0.02486 & 4.7552 & & & 1 & $1,920.4176$ & 0.05404 & $1.4450^{*}$ \\
\hline & & 2 & $1,663.6457$ & 0.01373 & & & & 2 & $1,921.1401$ & 0.00422 & \\
\hline & \multirow{3}{*}{ Palladium } & 0 & $1,521.2539$ & . & 16.1810 & & \multirow{3}{*}{ Palladium } & 0 & $1,760.5529$ & & 24.2835 \\
\hline & & 1 & $1,526.4424$ & 0.02971 & 5.8041 & & & 1 & $1,770.7432$ & 0.05785 & 3.9027 \\
\hline & & 2 & $1,529.3444$ & 0.01673 & & & & 2 & $1,772.6946$ & 0.01135 & \\
\hline & \multirow{3}{*}{ Silver } & 0 & $2,033.2569$ & . & 33.7277 & & \multirow{3}{*}{ Silver } & 0 & $1,726.5642$ & & 23.3600 \\
\hline & & 1 & $2,047.0528$ & 0.07644 & $6.1359^{*}$ & & & 1 & $1,737.1161$ & 0.05934 & $2.2562^{*}$ \\
\hline & & 2 & $2,050.1208$ & 0.01753 & & & & 2 & $1,738.2442$ & 0.00652 & \\
\hline \multirow{6}{*}{ Germany } & \multirow{3}{*}{ Platinum } & 0 & $2,122.9717$ & . & 32.0494 & \multirow{3}{*}{ Mexico } & \multirow{3}{*}{ Platinum } & 0 & $1,800.0031$ & & 26.1792 \\
\hline & & 1 & $2,136.4821$ & 0.07491 & $5.0286^{*}$ & & & 1 & $1,809.9669$ & 0.05612 & $6.2518^{*}$ \\
\hline & & 2 & $2,138.9964$ & 0.01439 & & & & 2 & $1,813.0928$ & 0.01796 & \\
\hline & \multirow{3}{*}{ Palladium } & 0 & $1,963.9575$ & . & 26.3393 & & \multirow{3}{*}{ Palladium } & 0 & $1,659.6616$ & $\cdot$ & 26.0222 \\
\hline & & 1 & $1,975.2200$ & 0.06285 & $3.8143^{*}$ & & & 1 & $1,670.4653$ & 0.06071 & $4.4146^{*}$ \\
\hline & & 2 & $1,977.1271$ & 0.01093 & & & & 2 & $1,672.6726$ & 0.01271 & \\
\hline
\end{tabular}

Note: ${ }^{*}$ stands for the failure to reject the null hypothesis at the respective rank. If the null hypothesis can not be rejected at rank 0 , the series are not cointegrated; if the null-hypothesis can not be rejected at rank 1 , the series are cointgrated with one cointgeration vector etc. 
Table 3b: Johansen Cointegration Test Results

\begin{tabular}{|c|c|c|c|c|c|c|c|c|c|c|c|}
\hline Country & Metal & $\begin{array}{l}\text { Max. } \\
\text { Rank }\end{array}$ & LL & & $\begin{array}{c}\text { Trace } \\
\text { Statistic }\end{array}$ & Country & Metal & $\begin{array}{l}\text { Max. } \\
\text { Rank }\end{array}$ & LL & & $\begin{array}{c}\text { Trace } \\
\text { Statistic }\end{array}$ \\
\hline & & 0 & $1,754.1527$ & . & 32.7610 & & & 0 & $1,784.4830$ & . & 47.0568 \\
\hline & Silver & 1 & $1,769.0563$ & 0.08323 & $2.9538^{*}$ & & Silver & 1 & $1,806.1351$ & 0.11828 & $3.7526^{*}$ \\
\hline & & 2 & $1,770.5332$ & 0.00857 & & & & 2 & $1,808.0114$ & 0.01085 & \\
\hline \multirow{9}{*}{ South Africa } & & 0 & $1,818.7546$ & . & 34.5730 & & & 0 & $1,873.4901$ & . & 49.1810 \\
\hline & Platinum & 1 & $1,833.4414$ & 0.08184 & $5.1994^{*}$ & United Kingdom & Platinum & 1 & $1,895.8993$ & 0.12282 & $4.3625^{*}$ \\
\hline & & 2 & $1,836.0411$ & 0.01500 & & & & 2 & $1,898.0806$ & 0.01267 & \\
\hline & & 0 & $1,661.8358$ & . & 36.7814 & & & 0 & $1,717.8391$ & . & 22.2513 \\
\hline & Palladium & 1 & $1,678.3342$ & 0.09121 & $3.7846^{*}$ & & Palladium & 1 & $1,725.0271$ & 0.04116 & 7.8752 \\
\hline & & 2 & $1,680.2265$ & 0.01091 & & & & 2 & $1,728.9648$ & 0.02276 & \\
\hline & & 0 & $1,778.7567$ & & 62.4012 & & & 0 & $1,992.3986$ & & 28.2779 \\
\hline & Silver & 1 & $1,806.9995$ & 0.15143 & $5.9157^{*}$ & & Silver & 1 & $2,005.1094$ & 0.07104 & $2.8562^{*}$ \\
\hline & & 2 & $1,809.9573$ & 0.01705 & & & & 2 & $2,006.5375$ & 0.00824 & \\
\hline \multirow{9}{*}{ South Korea } & & 0 & $1,877.4427$ & $\cdot$ & 40.3831 & & & 0 & $2,088.4933$ & . & 34.2486 \\
\hline & Platinum & 1 & $1,895.0011$ & 0.09731 & $5.2664^{*}$ & United States & Platinum & 1 & $2,104.0254$ & 0.08635 & $3.1844^{*}$ \\
\hline & & 2 & $1,897.6343$ & 0.01524 & & & & 2 & $2,105.6176$ & 0.00921 & \\
\hline & & 0 & $1,733.7410$ & & 34.5866 & & & 0 & $1,925.0291$ & . & 20.4068 \\
\hline & Palladium & 1 & $1,748.5517$ & 0.08228 & $4.9653^{*}$ & & Palladium & 1 & $1,932.6099$ & 0.04312 & 5.2453 \\
\hline & & 2 & $1,751.0344$ & 0.01429 & & & & 2 & $1,935.2325$ & 0.01513 & \\
\hline & & 0 & $1,865.0535$ & . & 54.1088 & & & & & . & \\
\hline & Silver & 1 & $1,889.7418$ & 0.13371 & 4.7323 & & & & & & \\
\hline & & 2 & $1,892.1080$ & 0.01366 & & & & & & & \\
\hline \multirow{6}{*}{ Switzerland } & & 0 & $1,944.3998$ & . & 60.1007 & & & & & . & \\
\hline & Platinum & 1 & $1,972.1688$ & 0.14909 & $4.5626^{*}$ & & & & & & \\
\hline & & 2 & $1,974.4502$ & 0.01318 & & & & & & & \\
\hline & & 0 & $1,791.3033$ & & 42.7491 & & & & & & \\
\hline & Palladium & 1 & $1,809.2724$ & 0.09975 & 6.8110 & & & & & & \\
\hline & & 2 & $1,812.6779$ & 0.01972 & & & & & & & \\
\hline
\end{tabular}

Note: * stands for the failure to reject the null hypothesis at the respective rank. If the null hypothesis can not be rejected at rank 0 , the series are not cointegrated; if the null-hypothesis can not be rejected at rank 1 , the series are cointgrated with one cointgeration vector etc. 
Table 4: Bierens and Martins (2010) Test for Time-Varying Cointegration

\begin{tabular}{|c|c|c|c|c|c|c|}
\hline Country & Metal & $\begin{array}{c}\text { Chebyshev Time } \\
\text { Polynomials }\end{array}$ & p value & $\begin{array}{c}\text { Test } \\
\text { Statistic }\end{array}$ & $\begin{array}{c}10 \% \\
\text { Critical Value }\end{array}$ & $\begin{array}{c}5 \% \\
\text { Critical Value }\end{array}$ \\
\hline \multirow{2}{*}{ Canada } & Platinum & 2 & 0.0017 & $17.29^{* *}$ & 7.78 & 9.49 \\
\hline & Palladium & 1 & 0.0007 & $14.53^{* *}$ & 4.61 & 5.99 \\
\hline \multirow{3}{*}{ Germany } & Silver & 2 & 0.01677 & $12.08^{* *}$ & 7.78 & 9.49 \\
\hline & Platinum & 1 & 0.00053 & $15.08^{* *}$ & 4.61 & 5.99 \\
\hline & Palladium & 1 & 0.02536 & $7.35 * *$ & 4.61 & 5.99 \\
\hline \multirow{3}{*}{ Italy } & Silver & 2 & 0.03482 & $10.36^{* *}$ & 7.78 & 9.49 \\
\hline & Platinum & 1 & 0.00018 & $17.27^{* *}$ & 4.61 & 5.99 \\
\hline & Palladium & 2 & 0.08648 & $8.14^{*}$ & 7.78 & 9.49 \\
\hline \multirow{2}{*}{ Japan } & Silver & 1 & 0.00582 & $10.29^{* *}$ & 4.61 & 5.99 \\
\hline & Platinum & 1 & 0.00211 & $12.33^{* *}$ & 4.61 & 5.99 \\
\hline \multirow{3}{*}{ Mexico } & Silver & 1 & 0.00079 & $14.3^{* *}$ & 4.61 & 5.99 \\
\hline & Platinum & 1 & 0.06578 & $5.44^{*}$ & 4.61 & 5.99 \\
\hline & Palladium & 3 & 0.04212 & $13.06^{* *}$ & 10.64 & 12.59 \\
\hline \multirow{3}{*}{$\begin{array}{l}\text { South } \\
\text { Africa }\end{array}$} & Silver & 2 & 0.0218 & $11.47^{* *}$ & 7.78 & 9.49 \\
\hline & Platinum & 2 & 0.00019 & $22.09^{* *}$ & 7.78 & 9.49 \\
\hline & Palladium & 1 & 0.00055 & $15.02^{* *}$ & 4.61 & 5.99 \\
\hline \multirow{3}{*}{$\begin{array}{l}\text { South } \\
\text { Korea }\end{array}$} & Silver & 3 & 0.0585 & $12.16^{*}$ & 10.64 & 12.59 \\
\hline & Platinum & 2 & 0.00153 & $17.52^{* *}$ & 7.78 & 9.49 \\
\hline & Palladium & 2 & 0.07313 & $8.56^{*}$ & 7.78 & 9.49 \\
\hline Switzerland & Platinum & 1 & 0.00064 & $14.72^{* *}$ & 4.61 & 5.99 \\
\hline United & Silver & 1 & 0.00235 & $12.11^{* *}$ & 4.61 & 5.99 \\
\hline Kingdom & Platinum & 1 & 0 & $26.57^{* *}$ & 4.61 & 5.99 \\
\hline United & Silver & 3 & 0.05959 & $12.11^{*}$ & 10.64 & 12.59 \\
\hline States & Platinum & 4 & 0.00566 & $21.62^{* *}$ & 13.36 & 15.51 \\
\hline
\end{tabular}

Note: ${ }^{* *}$ and $*$ stand for the rejection of the null hypothesis of time-invariance at the $5 \%$ and $10 \%$ level respectively, depending on a $10 \%$ confidence level p-value. The Bierens and Martins (2010) test approximates the cointegrating vector in the Johansen (1991) test by a finite number of Chebyshev time polynomials and can be used to determine whether or not the cointegrating vector varies with time. We follow Bampinas and Panagiotidis (2015) in reporting results for $\mathrm{m}$ up to four and conclude that time-variation is observed unless at least one $\mathrm{m}$ fails to rejects the null hypothesis. 
Table 5: Stability Test Results

\begin{tabular}{|c|c|c|c|c|c|}
\hline Country & Metal & $\sup _{\tau}\left|\hat{V}_{T}(\tau)\right|$ & $\begin{array}{c}1 \% \\
\text { Critical Value }\end{array}$ & $\begin{array}{c}5 \% \\
\text { Critical Value }\end{array}$ & $\begin{array}{c}10 \% \\
\text { Critical Value }\end{array}$ \\
\hline \multirow{3}{*}{ Canada } & Silver & $88.652^{* * *}$ & 5.785 & 4.308 & 3.652 \\
\hline & Platinum & $152.708^{* * *}$ & 4.598 & 3.166 & 2.666 \\
\hline & Palladium & $247.424^{* * *}$ & 10.418 & 7.607 & 5.708 \\
\hline \multirow{3}{*}{ China } & Silver & $8.743^{* * *}$ & 6.989 & 4.779 & 3.799 \\
\hline & Platinum & $6.699^{* * *}$ & 6.224 & 4.579 & 3.63 \\
\hline & Palladium & 4.792 & 7.89 & 5.705 & 5.127 \\
\hline \multirow{3}{*}{ Germany } & Silver & $238.569 * * *$ & 5.198 & 4.348 & 3.588 \\
\hline & Platinum & $279.452^{* * *}$ & 4.118 & 3.117 & 2.652 \\
\hline & Palladium & $348.352^{* * *}$ & 9.168 & 7.446 & 6.556 \\
\hline \multirow{3}{*}{ Italy } & Silver & $132.501^{* * *}$ & 8.622 & 5.399 & 4.464 \\
\hline & Platinum & $203.041^{* * *}$ & 5.964 & 4.344 & 3.496 \\
\hline & Palladium & $148.296^{* * *}$ & 13.532 & 8.858 & 6.634 \\
\hline \multirow{3}{*}{ Japan } & Silver & $1569.7^{* * *}$ & 8.568 & 6.137 & 4.873 \\
\hline & Platinum & $1785.6^{* * *}$ & 7.577 & 5.054 & 3.855 \\
\hline & Palladium & $1134^{* * *}$ & 10.229 & 7.586 & 6.328 \\
\hline \multirow{3}{*}{ Mexico } & Silver & $49.032^{* * *}$ & 14.666 & 10.164 & 8.611 \\
\hline & Platinum & $53.783^{* * *}$ & 8.905 & 7.708 & 6.18 \\
\hline & Palladium & $61.184^{* * *}$ & 29.521 & 18.49 & 13.637 \\
\hline \multirow{3}{*}{$\begin{array}{l}\text { South } \\
\text { Africa }\end{array}$} & Silver & $81.461^{* * *}$ & 8.582 & 6.934 & 5.728 \\
\hline & Platinum & $101.458^{* * *}$ & 8.774 & 6.43 & 4.925 \\
\hline & Palladium & $97.140^{* * *}$ & 14.981 & 10.708 & 8.723 \\
\hline \multirow{3}{*}{$\begin{array}{l}\text { South } \\
\text { Korea }\end{array}$} & Silver & $66.017^{* * *}$ & 7.481 & 5.432 & 4.45 \\
\hline & Platinum & $115.689^{* * *}$ & 5.146 & 3.984 & 3.384 \\
\hline & Palladium & $131.001^{* * *}$ & 11.808 & 7.585 & 6.267 \\
\hline \multirow{3}{*}{ Switzerland } & Silver & $684.967^{* * *}$ & 5.484 & 4.702 & 3.941 \\
\hline & Platinum & $1274.8^{* * *}$ & 4.506 & 3.524 & 3.098 \\
\hline & Palladium & $654.765^{* * *}$ & 8.282 & 6.41 & 4.729 \\
\hline \multirow{3}{*}{$\begin{array}{c}\text { United } \\
\text { Kingdom }\end{array}$} & Silver & $285.461^{* * *}$ & 7.531 & 5.577 & 4.432 \\
\hline & Platinum & $200.190^{* * *}$ & 4.735 & 3.681 & 3.119 \\
\hline & Palladium & $295.883^{* * *}$ & 11.268 & 8.412 & 5.817 \\
\hline \multirow{3}{*}{$\begin{array}{l}\text { United } \\
\text { States }\end{array}$} & Silver & $71.213^{* * *}$ & 6.206 & 4.036 & 3.403 \\
\hline & Platinum & $146.617^{* * *}$ & 4.455 & 3.345 & 2.636 \\
\hline & Palladium & $136.716^{* * *}$ & 6.975 & 5.788 & 4.914 \\
\hline
\end{tabular}

Note: $* * *, * *$, and $*$ indicates statistical significance at the $1 \%, 5 \%$, and $10 \%$ level respectively. 
Table 6: Individual Quantile Cointegration Analysis

\begin{tabular}{|c|c|c|c|c|c|c|}
\hline Country & Metal & $\tau=0.1$ & $\tau=0.25$ & $\tau=0.5$ & $\tau=0.75$ & $\tau=0.9$ \\
\hline \multirow{3}{*}{ Canada } & Silver & $3.1056^{* * *}$ & $3.1032^{* * *}$ & $3.1032^{* * *}$ & $3.0989^{* * *}$ & $3.1058^{* * *}$ \\
\hline & Platinum & $2.6003^{* * *}$ & $2.6017^{* * *}$ & $2.6017^{* * *}$ & $2.6029 * * *$ & $2.6021^{* * *}$ \\
\hline & Palladium & $3.1892^{* * *}$ & $3.1904^{* * *}$ & $3.1904^{* * *}$ & $3.186^{* * *}$ & $3.181 * * *$ \\
\hline \multirow{3}{*}{ China } & Silver & 0.1467 & 0.1408 & 0.1408 & 0.1345 & 0.1357 \\
\hline & Platinum & $0.1212^{* * *}$ & $0.1189^{* * *}$ & $0.1189^{* * *}$ & $0.1206^{* * *}$ & $0.1222^{* * *}$ \\
\hline & Palladium & $0.1645^{* * *}$ & $0.16^{* * *}$ & $0.16^{* * *}$ & $0.1655^{* * *}$ & $0.1714^{* * *}$ \\
\hline \multirow{3}{*}{ Germany } & Silver & $3.6258^{* * *}$ & $3.6357^{* * *}$ & $3.6357^{* * *}$ & $3.6412^{* * *}$ & $3.6352^{* * *}$ \\
\hline & Platinum & $3.0138 * * *$ & $3.0136^{* * *}$ & $3.0136^{* * *}$ & $3.0203^{* * *}$ & $3.018^{* * *}$ \\
\hline & Palladium & $3.9181^{* * *}$ & $3.9065^{* * *}$ & $3.9065^{* * *}$ & $3.9046^{* * *}$ & $3.9002^{* * *}$ \\
\hline \multirow{3}{*}{ Italy } & Silver & 2.5259 & 2.5272 & 2.5272 & 2.5259 & 2.5263 \\
\hline & Platinum & $2.1939^{* * *}$ & $2.1963^{* * *}$ & $2.1963^{* * *}$ & $2.1976^{* * *}$ & $2.194^{* * *}$ \\
\hline & Palladium & 2.7374 & 2.7768 & 2.7768 & 2.7814 & 2.7764 \\
\hline \multirow{3}{*}{ Japan } & Silver & 1.3695 & 1.3718 & 1.3718 & 1.3657 & 1.354 \\
\hline & Platinum & $0.3986 * * *$ & $0.4014^{* * *}$ & $0.4014^{* * *}$ & $0.4047 * * *$ & $0.3978^{* * *}$ \\
\hline & Palladium & $8.5305^{* * *}$ & $8.5231^{* * *}$ & $8.5231^{* * *}$ & $8.5155^{* * *}$ & $8.512^{* * *}$ \\
\hline \multirow{3}{*}{ Mexico } & Silver & 1.292 & 1.309 & 1.309 & 1.2962 & 1.2911 \\
\hline & Platinum & $1.2287^{* * *}$ & $1.2282^{* * *}$ & $1.2282^{* * *}$ & $1.2357^{* * *}$ & $1.2309^{* * *}$ \\
\hline & Palladium & 1.4579 & 1.4556 & 1.4556 & 1.4586 & 1.4443 \\
\hline \multirow{3}{*}{$\begin{array}{l}\text { South } \\
\text { Africa }\end{array}$} & Silver & 1.8325 & $1.8262^{* * *}$ & $1.8262^{* * *}$ & $1.8249^{* * *}$ & $1.8237^{* * *}$ \\
\hline & Platinum & 1.6681 & 1.6568 & $1.6568^{*}$ & $1.653^{* *}$ & $1.6494^{* *}$ \\
\hline & Palladium & 1.9165 & 1.9096 & 1.9096 & 1.9047 & 1.9188 \\
\hline \multirow{3}{*}{$\begin{array}{l}\text { South } \\
\text { Korea }\end{array}$} & Silver & 2.276 & 2.2777 & 2.2777 & 2.2754 & 2.2713 \\
\hline & Platinum & $2.0221^{* * *}$ & $2.0246^{* * *}$ & $2.0246^{* * *}$ & $2.0276^{* * *}$ & $2.028^{* * *}$ \\
\hline & Palladium & $2.4548^{* *}$ & $2.4587^{* *}$ & $2.4587^{* *}$ & $2.4575^{* *}$ & $2.4595^{* *}$ \\
\hline \multirow{3}{*}{ Switzerland } & Silver & $3.3758^{* * *}$ & $3.3749^{* * *}$ & $3.3749^{* * *}$ & $3.3696^{* * *}$ & $3.367^{* * *}$ \\
\hline & Platinum & $2.8063^{* * *}$ & $2.8102^{* * *}$ & $2.8102^{* * *}$ & $2.8115^{* * *}$ & $2.8039^{* * *}$ \\
\hline & Palladium & $4.0733^{* * *}$ & $4.0857^{* * *}$ & $4.0857^{* * *}$ & $4.0873^{* * *}$ & $4.0856^{* * *}$ \\
\hline \multirow{3}{*}{$\begin{array}{c}\text { United } \\
\text { Kingdom }\end{array}$} & Silver & $3.0531^{* * *}$ & $3.05^{* * *}$ & $3.05^{* * *}$ & $3.0383^{* * *}$ & $3.0375^{* * *}$ \\
\hline & Platinum & $2.4882^{* * *}$ & $2.4796^{* * *}$ & $2.4796^{* * *}$ & $2.4808^{* * *}$ & $2.4775^{* * *}$ \\
\hline & Palladium & $3.2149^{* * *}$ & $3.2191^{* * *}$ & $3.2191^{* * *}$ & $3.2173^{* * *}$ & $3.2129^{* * *}$ \\
\hline \multirow{3}{*}{$\begin{array}{l}\text { United } \\
\text { States }\end{array}$} & Silver & 2.7306 & $2.725^{* * *}$ & $2.725^{* * *}$ & $2.7292^{* * *}$ & $2.732^{* * *}$ \\
\hline & Platinum & 2.3161 & $2.3268^{* * *}$ & $2.3268^{* * *}$ & $2.3289^{* * *}$ & $2.3307^{* * *}$ \\
\hline & Palladium & 2.8311 & $2.8411^{* * *}$ & $2.8411^{* * *}$ & $2.841^{* * *}$ & $2.8339^{* * *}$ \\
\hline
\end{tabular}

Note: $* * *, * *$, and $*$ indicates statistical significance at the $1 \%, 5 \%$, and $10 \%$ level respectively. 
Figure 1: Plot of Johansen's Trace Statistic scaled by the $5 \%$ Critical Value - Canada

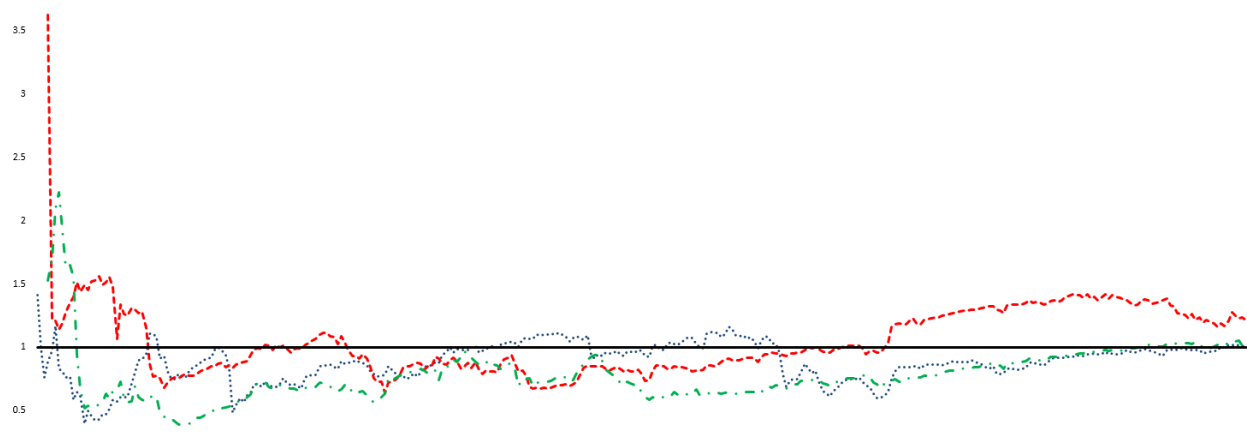

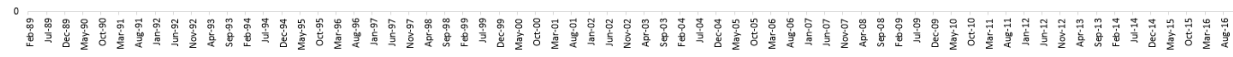

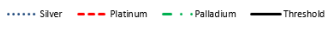

Figure 2: Plot of Johansen's Trace Statistic scaled by the 5\% Critical Value - China

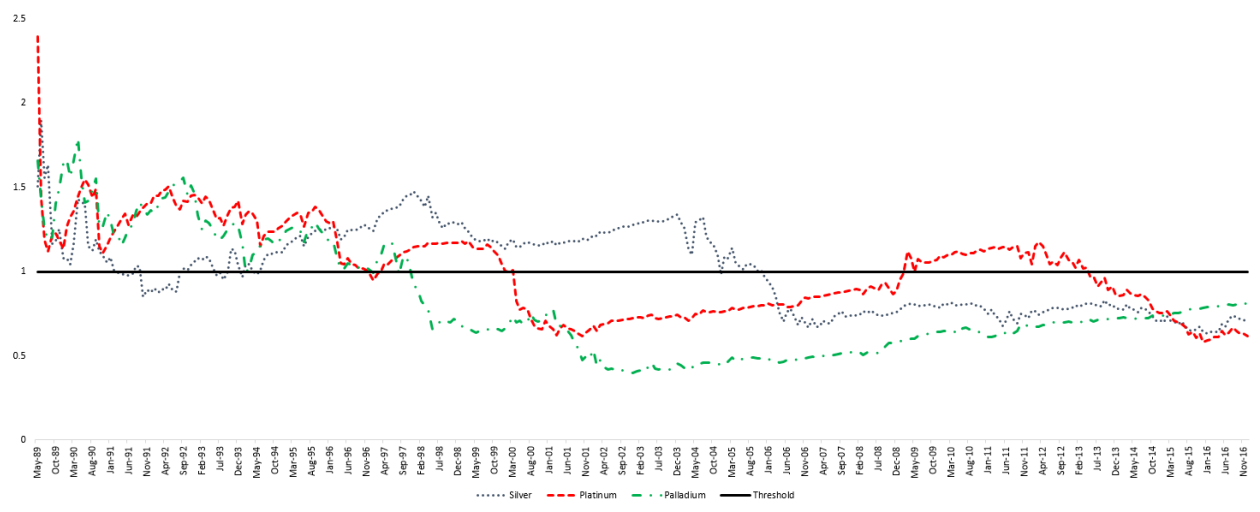


Figure 3: Plot of Johansen's Trace Statistic scaled by the 5\% Critical Value - Germany

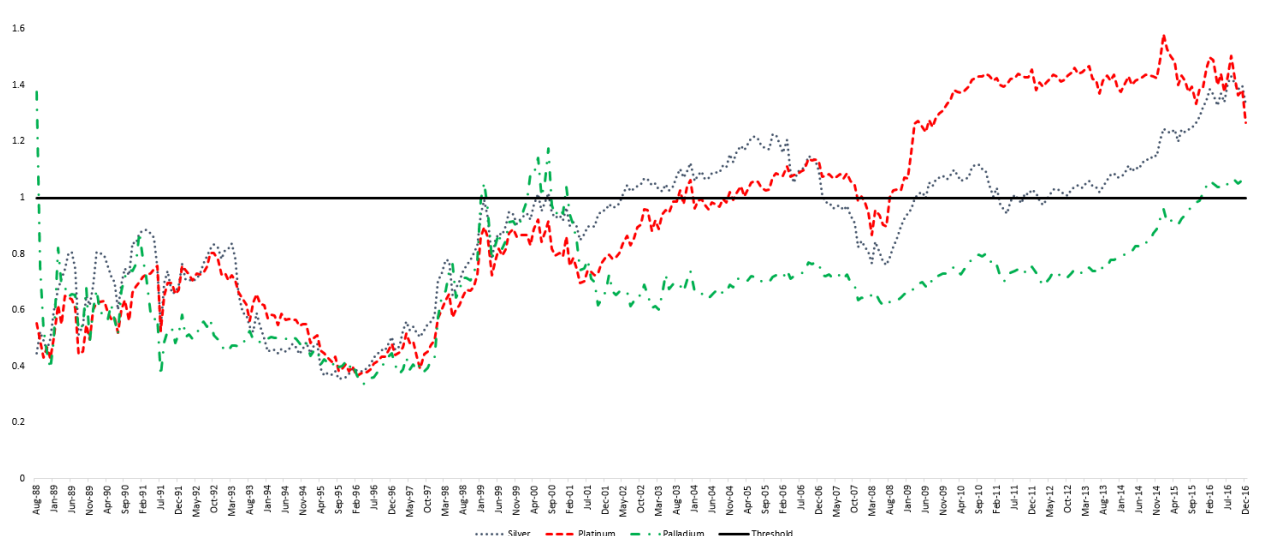

Figure 4: Plot of Johansen's Trace Statistic scaled by the 5\% Critical Value - Italy

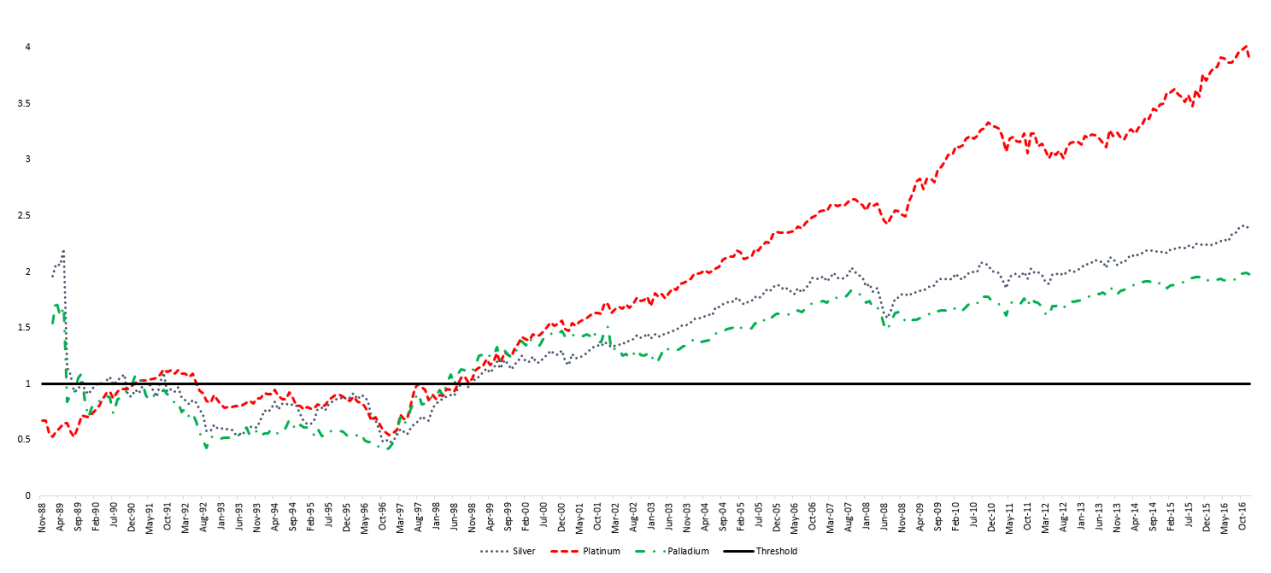


Figure 5: Plot of Johansen's Trace Statistic scaled by the 5\% Critical Value - Japan

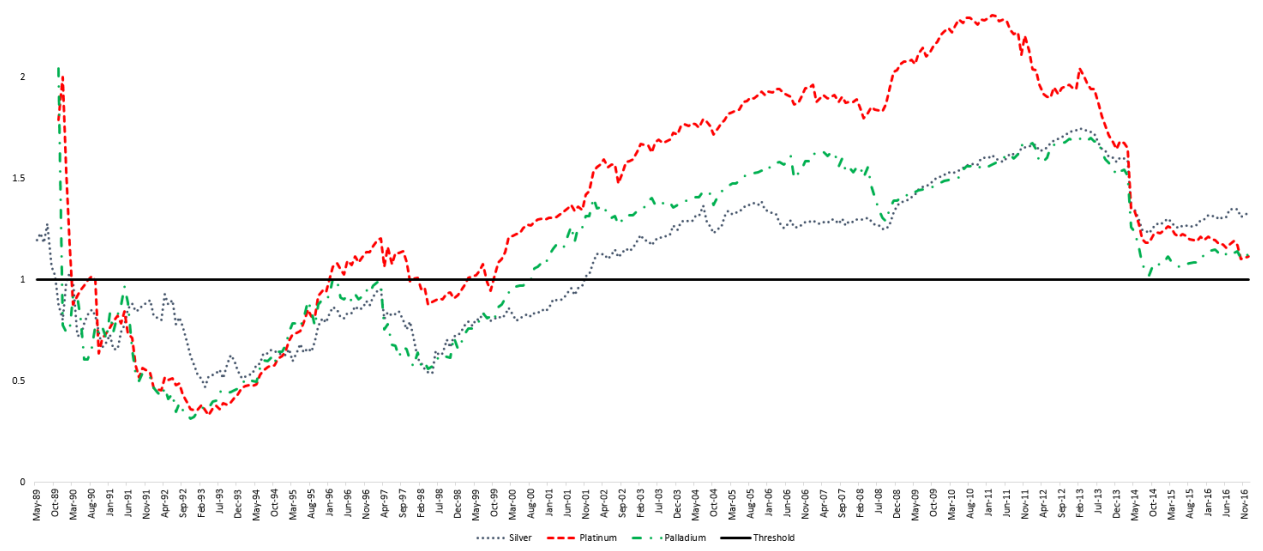

Figure 6: Plot of Johansen's Trace Statistic scaled by the 5\% Critical Value - Mexico

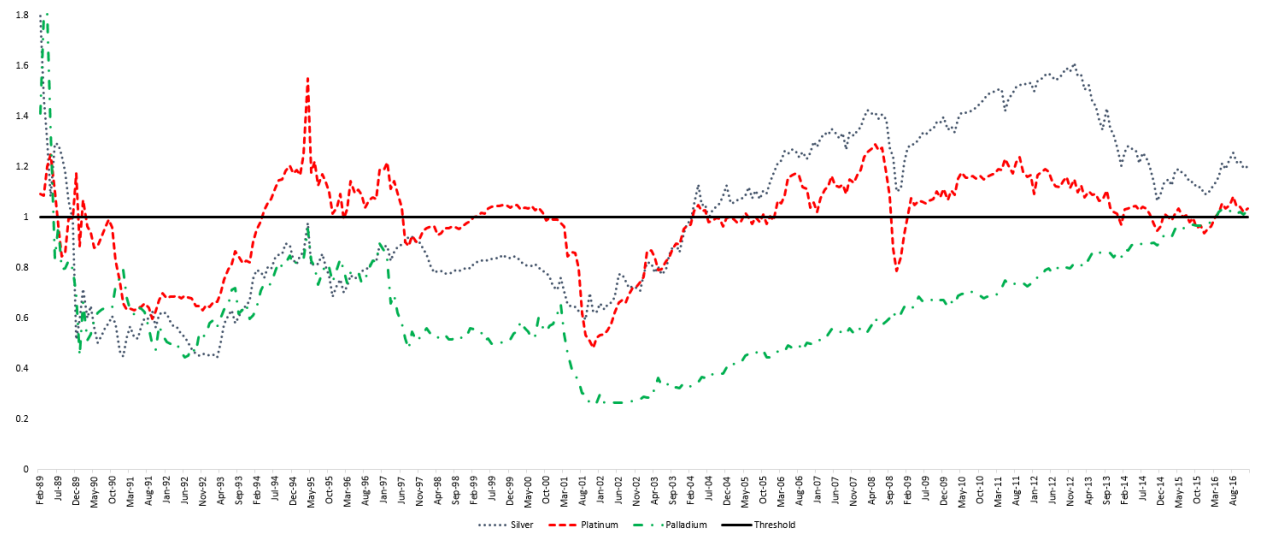


Figure 7: Plot of Johansen's Trace Statistic scaled by the 5\% Critical Value - South Africa

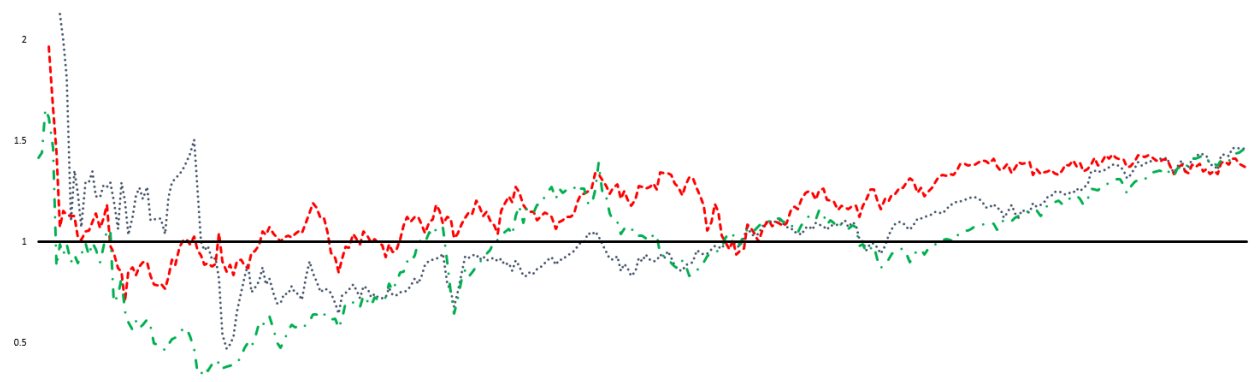

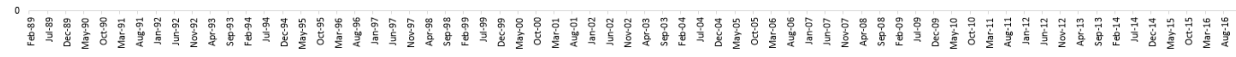

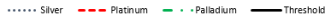

Figure 8: Plot of Johansen's Trace Statistic scaled by the $5 \%$ Critical Value - South Korea

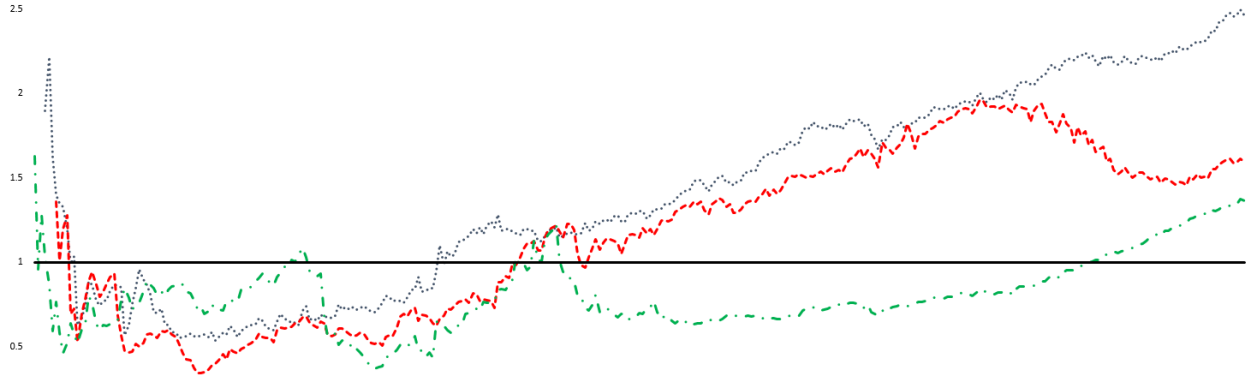

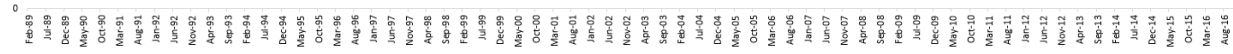

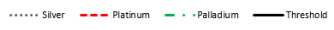


Figure 9: Plot of Johansen's Trace Statistic scaled by the $5 \%$ Critical Value - Switzerland

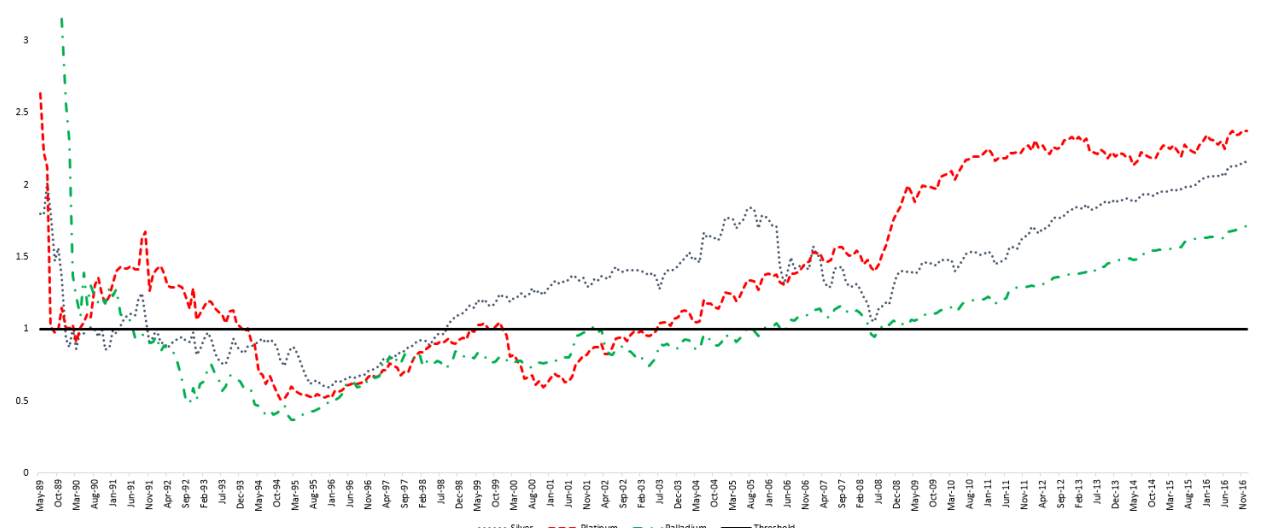

Figure 10: Plot of Johansen's Trace Statistic scaled by the $5 \%$ Critical Value - United Kingdom

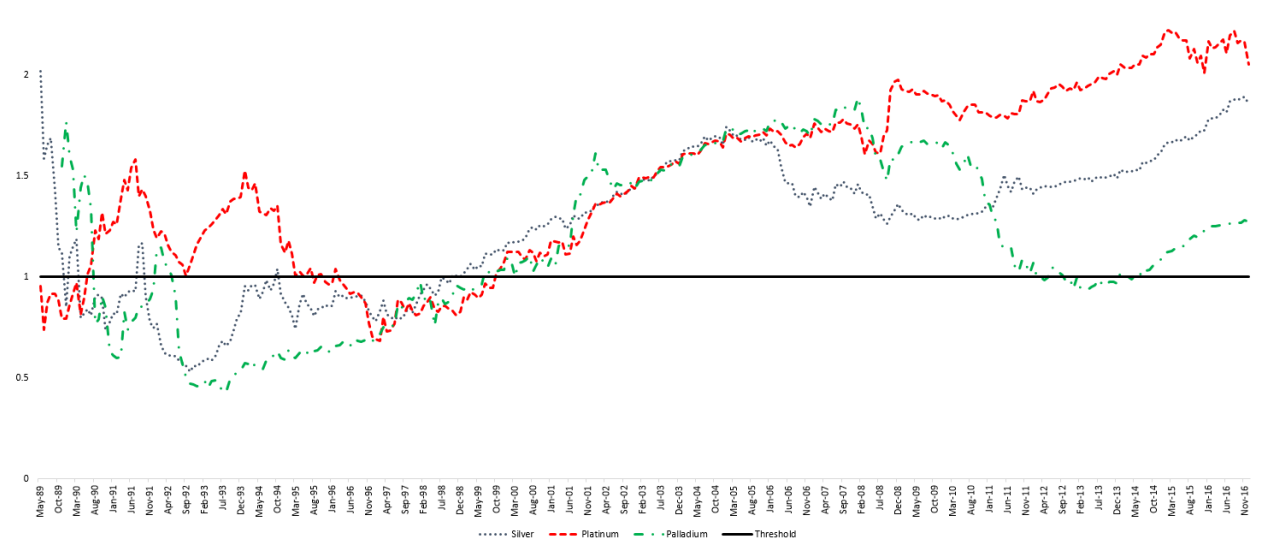


Figure 11: Plot of Johansen's Trace Statistic scaled by the 5\% Critical Value - United States

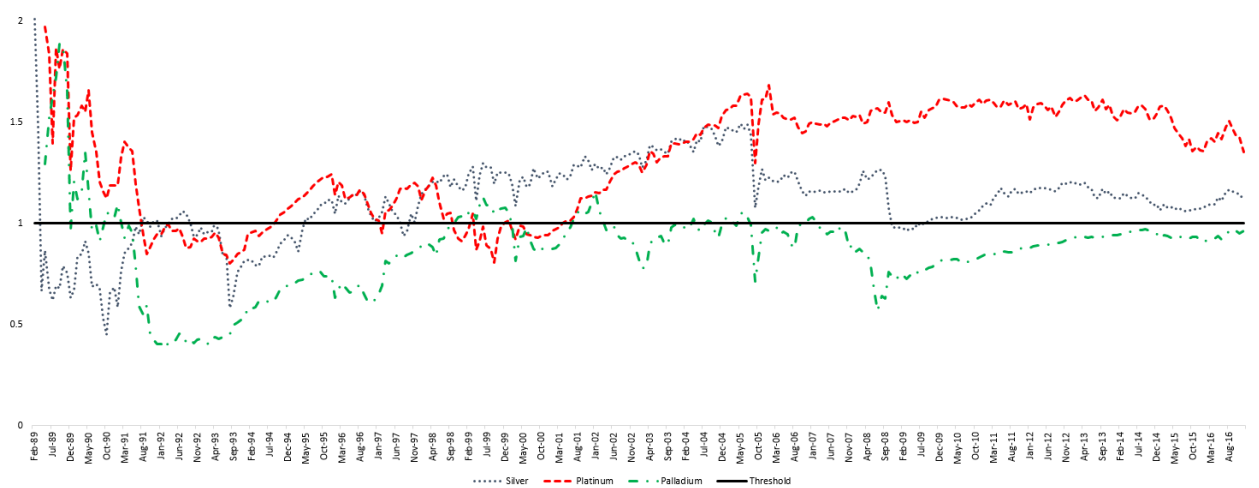

